\title{
New records and host plants of Symphyta (Hymenoptera) for Germany, Berlin and Brandenburg
}

With 10 figures

ANDREW D. LISTON ${ }^{1}$

${ }^{1}$ Senckenberg Deutsches Entomologisches Institut, Eberswalder Straße 90, 15374 Müncheberg, Germany. - aliston@senckenberg.de Published on 2015-12-21

\section{Summary}

24 species of sawflies are recorded for the first time in Brandenburg and / or Berlin. Four of these are new records for Germany: Dineura parcivalvis (Konow, 1901), Euura plicadaphnoides (Kopelke, 2007), Pristiphora angulata Lindqvist, 1974 and Tenthredo semicolon MoL, 2013. It is not clear whether P. angulata is established in Germany. Empria hungarica (Konow, 1895) is new for Rhineland-Palatinate. The presence of Calameuta punctata in Brandenburg is confirmed. Dineura testaceipes is removed from the list of Berlin-Brandenburg species. Linum usitatissimum is a new host plant for Rhogogaster chambersi BENSON, 1947 and Salix daphnoides for Ametastegia perla (KLUG, 1818).

\section{Key words}

Tenthredinoidea, Pamphiliidae, Cephidae, Xiphydriidae, distribution, host plants

\section{Zusammenfassung}

Erstnachweise von 24 Arten Pflanzenwespen aus Brandenburg und / oder Berlin werden gemeldet. Vier von diesen Arten sind Erstnachweise für Deutschland: Dineura parcivalvis (Konow, 1901), Euura plicadaphnoides (KopelKe, 2007), Pristiphora angulata Lindqvist, 1974 und Tenthredo semicolon Mol, 2013. Es ist nicht klar, ob P. angulata in Deutschland etabliert ist. Empria hungarica (Konow, 1895) ist neu für Rheinland-Pfalz. Ein Vorkommen von Calameuta punctata in Brandenburg wird bestätigt. Dineura testaceipes wird aus der Fauna von Brandenburg / Berlin gestrichen. Linum usitatissimum ist eine neue Larvenwirtspflanze für Rhogogaster chambersi Benson, 1947 und Salix daphnoides für Ametastegia perla (KLUG, 1818).

\section{Introduction}

During the 19th Century, several entomologists resident in what are now the German federal states of Berlin and Brandenburg laid the foundations for studies on the sawfly fauna of these territories. Most prominent among such pioneers were FrIEDRICH KLUG (1775-1856) and Theodor Hartig (1805-1880), whose taxonomic work was based partly on material obtained in the region.
Although he published little about Symphyta occurring in or around Berlin, JohanN P. E. F. STEIN (ca. 1816-1882, exact dates unclear) continued this tradition by building up and curating the collection at the Museum of Natural History in Berlin. The collection of FrIEDRICH WILHELM Konow (1842-1908), deposited at the Senckenberg Deutsches Entomologisches Institut, Müncheberg, also 
contains many specimens from Brandenburg. By contrast, after the publication of the important work by CARL SCHIRMER (1855-ca. 1919) (SCHIRMER 1901), investigation of the regional fauna was comparatively neglected during much of the 20th Century. Species lists for BerlinBrandenburg by BLANK et al. (1998) and BLANK et al. (2001) drew attention to deficits in the inventory of the fauna. It was accordingly not surprising, that LISTON (2006b) was able to present data for 112 species not previously recorded in these German federal states. Since the publication of that work, a number of records of further species new to the regional fauna have accumulated. These are presented here, together with data on species previously unconfirmed, that are only known from very old specimens, or for which new observations on host plants have been made. Notes on larval host plants are included when these were not summarised by TAEgER et al. (1998) or Liston et al. (2012).

\section{Material and methods}

If not stated otherwise, specimens were collected and determined by the author and are deposited in the Senckenberg Deutsches Entomologisches Institut, Müncheberg (SDEI). Where other specialists are named as having determined specimens, I checked the identity of these, to the best of my ability. The responsibility for any inaccuracies naturally remains my own.

All coordinates (decimal system) are for a central point. The coordinates of localities whose position is fairly precisely known (such as sites of Malaise traps, small private gardens, and main stems of individual trees or bushes), are given to the fifth decimal place after the degrees, with an accuracy of $\pm 20 \mathrm{~m}$. Coordinates of localities named on data labels are more approximate and given either to three decimal places with an accuracy of $\pm 2 \mathrm{~km}$ (mostly own records), or to two decimal places with a notional accuracy of $\pm 5 \mathrm{~km}$ (mostly older label data).

Photos were taken with a Leica DFC295 camera attached to an Olympus SZX12 microscope. Composite images with an extended depth of field were created using the software CombineZ5. Contrast and brightness of images was adjusted using the software PhotoImpact XL (Ulead Systems Inc.).

Barcoding of the mitochondrial CO1 gene of Dineura species was undertaken by the Canadian Centre for DNA Barcoding (CCDB). DNA extraction from a single leg of each adult specimen was followed by PCR amplification and sequencing using standardised high-throughput protocols (Ivanova et al. 2006, DeWAARD et al. 2008). The DNA extracts are stored at the CCDB, the vouchers at the SDEI. Sequences were aligned using the BOLD (Barcoding of Life Data Systems) Aligner. Genetic distances were calculated using analytical tools in BOLD, applying the
Kimura 2-parameter model, and the interspecific divergence given as the minimum pair-wise distance.

\section{Results}

The order of families follows BLANk et al. (2001). Genera and species are listed alphabetically. Nomenclature is after Liston et al. (2012), modified for the Nematinae following Prous et al. (2014). Names of species recorded for the first time from Berlin-Brandenburg are preceded by an asterisk $\left(^{\star}\right)$.

\section{Argidae}

${ }^{*}$ Arge metallica (KLUG, 1834)

Brandenburg: 1 ㅇ, Landkreis Oberhavel, Schildow, $52.64^{\circ} \mathrm{N} 13.37^{\circ} \mathrm{E}, 24.07 .1941$, leg. Hedicke, determined in 1976 as A. clavicornis expansa by W. H. Muche.

This species occurs very locally in Central Europe and is generally rarely recorded. SchedL \& Altenhofer (2013) presented valuable new data on its larva.

\section{Tenthredinidae}

\section{${ }^{*}$ Allantus melanarius (KLUG, 1818)}

Berlin: 1 ㅇ , Berlin, „28/4”, leg. Schirmer (in coll. Swedish Museum of Natural History, Stockholm). Brandenburg: 1 온, Landkreis Märkisch-Oderland, Buckow, $52.56^{\circ} \mathrm{N}$ $14.08^{\circ} \mathrm{E}$, „[?] 25/5“, leg. Schirmer (in coll. Swedish Museum of Natural History, Stockholm). 1 ㅇ, Landkreis Märkisch-Oderland, Müncheberg, ZALF Gelände, $52.51499^{\circ} \mathrm{N} 14.11548^{\circ} \mathrm{E}$, Malaise trap, 25.07.-01.08.2011. Only Cornus sanguinea is so far recorded as a larval host, but because $A$. melanarius is found not just in semi-natural habitats in which this shrub occurs, but also in parks and gardens where several other Cornus spp. are planted, it would be interesting to know whether some of these are used as hosts.

\section{*Ametastegia perla (KLUG, 1818)}

Brandenburg: 1 ㅇ, Müncheberg, ZALF Gelände, $52.515^{\circ} \mathrm{N} 14.115^{\circ} \mathrm{E}$, reared from Salix daphnoides, larva collected 29.06.2014, leg. M. Prous.

S. daphnoides is a new host plant record for this species.

\section{${ }^{*}$ Apethymus apicalis (KLUG, 1818)}

Brandenburg: $10^{\star}$, Landkreis Märkisch-Oderland, Müncheberg, $52.50556^{\circ} \mathrm{N} 14.12648^{\circ} \mathrm{E}$, Hausgarten, 11.10.2013, leg. S. M. Blank. 5 đ’ $^{\star}$ Landkreis Frankfurt (?), 
„Frankfurt / O.“, $52.35^{\circ} \mathrm{N} 14.55^{\circ} \mathrm{E}, 04.10 .1857$, leg. Zeller (in coll. National Museums of Scotland, Edinburgh).

The specimens collected by Zeller may either be from Germany, or from the part of former Frankfurt (now Slubice), east of the River Oder, that is now in Poland.

\section{${ }^{*}$ Apethymus serotinus (0. F. MüLLER, 1776)}

Brandenburg: 1 ㅇ , Landkreis Märkisch-Oderland, Waldsieversdorf, Lindenplatz, $52.539^{\circ} \mathrm{N} 14.054^{\circ} \mathrm{E}, 26.09 .2011$, leg. S. M. Blank; 1 , 28.09.2011.

\section{${ }^{*}$ Caliroa cothurnata (SERVILLE, 1823)}

Brandenburg: 1 우 Landkreis Barnim, Eberswalde, Waldstraße, garden and woodland edge, $52.82620^{\circ} \mathrm{N}$ $13.84100^{\circ} \mathrm{E}$, Malaise trap, 03-10.08.2002, leg. A. Taeger.

\section{*Dineura parcivalvis (Konow, 1901)}

Brandenburg: 2 + , Landkreis Märkisch-Oderland, Waldsieversdorf, $52.548^{\circ} \mathrm{N} 14.065^{\circ} \mathrm{E}, 19 / 25.05 .2006$, swept from Prunus padus.

First record from Germany.

These specimens were identified by LisTon (2006b) as D. testaceipes (KLUG). Muche (1968) also recorded D. testaceipes from Brandenburg. Although it is highly probable that $D$. testaceipes does occur here, no voucher specimens have so far been examined. Accordingly, $D$. testaceipes is deleted from the faunal list of BerlinBrandenburg. D. parcivalvis und D. testaceipes are morphologically very similar, although LINDQVIST (1955, 1972) noted conspicuous differences in the structure of the male penis valves. I had no males of $D$. parcivalvis available for examination. The most reliable single external character for distinguishing females seems to be the length of the antenna and proportions of the flagellomeres, at least in European specimens. However, two females in the SDEI from the Russian Far East, with characters that otherwise fit $D$. testaceipes, have more slender flagellomeres, like $D$. parcivalvis. The body colour of $D$. parcivalvis females is always relatively pale, with the abdomen underside extensively pale (yellow). The coloration of $D$. testaceipes varies much more than in D. parcivalvis, but most specimens of the former are darker than the latter. Most $D$. testaceipes imagines from northern Europe can be identified using only colour characters: the underside of the abdomen is usually nearly entirely dark (black / dark brown). On the other hand, some Austrian individuals reared from Sorbus aucuparia have been examined, that are just as pale as D. parcivalvis. Other characters mentioned by LINDQVIST seem less useful. The presence or absence of vein $2 r-r s$ in the fore wing is certainly not a good character: this varies in both species. There is indeed a slight difference in the sculpture of the upper head, particularly on the temples, but this is difficult to judge without direct comparison of both species. The colour of the pterostigma, as mentioned by LINDQvist (1955), seems to be of help in identification, but this needs to be checked in a greater number of specimens. Provisionally, females can be distinguished as follows:

Apical flagellomeres at least $5 \mathrm{x}$ as long as greatest width (Fig. 1). Abdominal sterna always mostly pale (Fig. 2). Pterostigma and costa brown (Fig. 2). Upper head more densely punctate, thus less shiny.

D. parcivalvis

Apical flagellomeres at most $4.5 \mathrm{x}$ as long as greatest width (Fig. 3). Abdominal sterna entirely black except around hypopygium (Fig. 4), or more or less pale. Pterostigma (at least in middle) and costa yellowish (Fig. 4). Upper head less densely punctate, thus more shiny. D. testaceipes

The identification of the D. parcivalvis specimens from Brandenburg is further supported by two non-morphological characters: a significant divergence in $\mathrm{CO} 1$ barcoding $(4.4 \%)$ from $D$. testaceipes and the fact that both females were collected from Prunus padus. KontuNIEmi (1960) established that Prunus padus is the larval host of D. parcivalvis. On the other hand, D. testaceipes has generally been regarded as monophagous on Sorbus aucuparia (e.g. Benson 1958). Previously, D. parcivalvis has been definitely recorded only from Finland, Estonia and Latvia, but possibly also occurs in Moravia, Czech Republic (see LiNDQvist 1955). Its global range reaches to the Russian Far East: 1 \% , Khabarovskiy Kray, Bikin N 20 km, Boitsovo, Bolshoi Sontsepyok Hill, 47.033 N $134.350^{\circ} \mathrm{E}, 26.05 .1993$, leg. A. Taeger (SDEI); 1 우 Primorskij Kray, Partisan, $13 \mathrm{~km} \mathrm{~S}$ Ussuriysk, $43.691^{\circ} \mathrm{N}$ $131.957^{\circ} \mathrm{E}, 15.06 .1993$, leg. A. Taeger (SDEI).

\section{*Dolerus brevicornis ZADDACH, 1859}

Brandenburg: 1 우 Landkreis Havelland, Falkensee [„Berlin-Finkenkrug“], $52.55^{\circ} \mathrm{N} 13.08^{\circ} \mathrm{E}, 29.04 .1918$, leg. [unknown], det. M. Heidemaa. 1 ㅇ, Landkreis MärkischOderland, Hennickendorf, Torfhaus, $52.517^{\circ} \mathrm{N} 13.844^{\circ} \mathrm{E}$, 25.04.2010. 3 우, Müncheberg, NSG Gumnitz, $52.509^{\circ} \mathrm{N}$ 14.080 $\mathrm{E}, 30.04 .2010$.

Distinguished from Dolerus asper ZADDACH, 1859 by HeidemaA et al. (2004), but still very under-recorded in Germany. The only published record is from Bavaria (Liston 2011). The following specimens from other German provinces were examined:

Mecklenburg-Vorpommern: 1 으, Landkreis Vorpommern-Rügen, Prerow, 04.05.1988, leg. Wrase, det. M. Heidemaa. Sachsen: $10^{\star}$, Leipzig, 22.03.1896, leg. Krieger, det. M. Heidemaa. Sachsen-Anhalt: 1 \% , Dessau, Beckerbruch, 22.04.1975, leg. A. Taeger, det. M. Heidemaa. Thüringen: 1 , Oberhof, Veilchenbrunnen, 26.05. 1989, leg. A. Taeger, det. M. Heidemaa. 


\section{*Dolerus harwoodi Benson, 1947}

Brandenburg: 1 ㅇ, Landkreis Havelland, Falkensee [„Berlin-Finkenkrug“], $52.55^{\circ} \mathrm{N} \quad 13.08^{\circ} \mathrm{E}, 29.04 .1918$, leg. [unknown], det. M. Heidemaa. $20^{\star}$, Landkreis Barnim, Eberswalde S, Paschenberg, $52.83^{\circ} \mathrm{N} 13.83^{\circ} \mathrm{E}$, 14/17.04.1982, leg. [unknown], det. M. Heidemaa. 1 ㅇ, Umg. Eberswalde, Biesenthal, $52.76^{\circ} \mathrm{N}$ $13.64^{\circ} \mathrm{E}, 08.05 .1971$, leg. J. Oehlke, det. A. Taeger / M. Heidemaa.

\section{*Dolerus uliginosus (KLUG, 1818)}

Brandenburg: 1 ㅇ, Landkreis Barnim, Ziethen, Grumsiner Forst, Langer Berg, Malaisefalle M4, $52.97500^{\circ} \mathrm{N}$ 13.91667 ${ }^{\circ} \mathrm{E}, 11 .-13.05 .1993$, leg. DEI; $1 \sigma^{\star}$, 26.04.04.05.1994, leg. DEI; 2 ơ, 1 ㅇ , 11.-18.05.1994, leg. DEI.

\section{*Empria basalis LINDovist, 1968}

Brandenburg: 3 ㅇ, Landkreis Märkisch-Oderland, Trebnitzer Schloßpark, $52.533^{\circ} \mathrm{N} 14.222^{\circ} \mathrm{E}, 09.05 .2010$, det. M. Prous. Netted from Geum urbanum, a probable host plant (Prous et al. 2011).

Probably a widespread species in Germany, but here hitherto not distinguished from related taxa (see Prous et al. 2011) and so far only recorded in Hesse (LöHR 2015).

\section{*Empria hungarica (Konow, 1895)}

Brandenburg: 1 ㅇ, $3 \sigma^{*}$, Landkreis Märkisch-Oderland, Oderhänge bei Dolgelin, $52.499^{\circ} \mathrm{N} 14.436^{\circ} \mathrm{E}, 25.04 .2010$; 2 ㅇ $6 \sigma^{*}, 02.05 .2010$. Landkreis Märkisch-Oderland, Oderhängen bei Mallnow, $52.466^{\circ} \mathrm{N} 14.500^{\circ} \mathrm{E}, 1$ ㅇ, $2 \mathrm{o}^{\mathrm{T}}$, 08.05.2010; 1 우, 01.05.2011.

Until now, the only recent German records of the species were from a single locality in Lower Bavaria (Liston et al. 2012). In addition to a historical record from Anhalt-Saxony (Liston 2006a), I have also seen a specimen from the Rhine-Palatinate: $10^{*}$, Naturschutzgebiet Dannstadt, 03.05.1949, leg. Zirngiebl, Zoologische Staatssammlung München. First record from Rhine-Palatinate.

\section{*Euura ampla (Konow, 1895) comb. nov.} [= Amauronematus amplus Konow, 1895]

Brandenburg: 1 ㅇ, Landkreis Barnim, Ziethen, Grumsiner Forst, Langer Berg, Malaisefalle M4, $52.97500^{\circ} \mathrm{N}$ 13.91667º E, 08.05.1996, leg. DEI.
*Euura ferruginea (FöRSTER, 1854) comb. nov.

[= Nematus ferrugineus FöRSTER, 1854]

Brandenburg: 1 ㅇ, Landkreis Barnim, Ziethen, Grumsiner Forst, Langer Berg, $52.97500^{\circ} \mathrm{N} 13.91667^{\circ} \mathrm{E}$, Malaisefalle M4, 12.06.1996, leg. DEI.

* Euura longiserra (Thomson, 1863) comb. nov. [= Nematus longiserra Thomson, 1863]

Brandenburg: 1 , Landkreis Märkisch-Oderland, Müncheberg, Waldsieversdorf, $52.548^{\circ} \mathrm{N} 14.103^{\circ} \mathrm{E}, 24.04$. 2005.

*Euura miltonota (ZADDACH, 1863) comb. nov. [= Nematus miltonotus ZADDACH, 1863]

Brandenburg: 1 , Landkreis Märkisch-Oderland, Müncheberg, $52.50843^{\circ} \mathrm{N} 14.13896^{\circ} \mathrm{E}, 20.04 .2009 .1$ 우, Landkreis Märkisch-Oderland, Prädikow, $52.633^{\circ} \mathrm{N}$ $14.008^{\circ} \mathrm{E}, 01.05 .2011$. Both swept from Salix viminalis.

* Euura plicadaphnoides (KOPELKE, 2007) comb. nov. [= Phyllocolpa plicadaphnoides KoPELKE, 2007]

Brandenburg: 5 우 $20^{\star}$, Landkreis Märkisch-Oderland, Müncheberg, ZALF Gelände, $52.515^{\circ} \mathrm{N} 14.115^{\circ} \mathrm{E}$, 20-26.04.2009; 1 ㅇ, 30.04.2010. All specimens swept from Salix daphnoides. Numerous larvae and leaf-folds (Figs 5-6) on S. daphnoides, Müncheberg, Seelower Str., $52.50150^{\circ} \mathrm{N} 14.15320^{\circ} \mathrm{E}$, June 2013.

First records from Germany.

This species was described from the Alpine regions of Austria and Switzerland (Kopelke 2007), and is monophagous on Salix daphnoides, which in Germany is native only to the Alps and the associated river systems. However, it has been widely planted outside its natural range because of its attractive appearance and utility as a food source for honeybees. BENEš (2015) recorded E. plicadaphnoides from the Czech Republic. In contrast to Euura acutifoliae (ZINovjev, 1985), another gallmaking sawfly on S. daphnoides, that is widespread throughout Germany, galls of E. plicadaphnoides have in Germany so far only been found in Müncheberg.

*Euura salicispurpureae KOPELKE, 2014 [= Euura purpureae KOPELKE, 1996: secondary homonym]

Brandenburg: 2 \& , Landkreis Märkisch-Oderland, Müncheberg, ZALF Gelände, $52.515^{\circ} \mathrm{N} 14.115^{\circ} \mathrm{E}, 30.04 .2010$. Swept from Salix purpurea. 


\section{Macrophya rufipes (LINNAEUS, 1758)}

Brandenburg: $1 \sigma^{\star}$, Landkreis Märkisch-Oderland, Müncheberg, ZALF Gelände, $52.515^{\circ} \mathrm{N} 14.115^{\circ} \mathrm{E}, 10.07 .2011$. The species had only once been recorded from BerlinBrandenburg, in the 19th Century in Berlin (Liston 2006b).

\section{*Pristiphora angulata LINDQviST, 1974}

Brandenburg: 1 ㅇ, Landkreis Barnim, Eberswalde, Ammon Park, $52.832^{\circ} \mathrm{N} 13.816^{\circ} \mathrm{E}, 27.04 .1989$, leg. A. Taeger, det. M. Prous \& A. Liston.

First record from Germany.

The recorded global distribution of Pristiphora angulata comprises only Norway (LøNNVE 2009), Finland (type locality: southern Finland), Estonia and northwest Russia (TAEgER et al. 2006). Host plants are Spiraea species, S. chamaedryfolia being a main host (LøNNVE 2009; A. Liston, personal observations). No Spiraea species is native in Fennoscandia or Germany, and the geographic origin of the neozoon $P$. angulata is unclear.

\section{Pristiphora parva (HARTIG, 1837)}

Brandenburg: 1 ㅇ, Landkreis Märkisch-Oderland, Münchehofe, Gr. Klobichsee, $52.555^{\circ} \mathrm{N} 14.128^{\circ} \mathrm{E}, 10.05 .2014$.

Not found in Berlin-Brandenburg since the type series was collected.

\section{Pristiphora wesmaeli (TISCHBEIN, 1853)}

Brandenburg: 1 ㅇ, Landkreis Barnim, Ziethen, Grumsiner Forst, Langer Berg, $52.97500^{\circ} \mathrm{N} 13.91667^{\circ} \mathrm{E}$, Malaisefalle M4, 24.05.1995, leg. DEI.

Confirmed as present in Brandenburg.

Liston (2006b) recorded P. glauca Benson, 1954, in Brandenburg, but not $P$. wesmaeli. The species are biologically and morphologically similar. The occurrence of P. wesmaeli in Brandenburg had however already been indicated by ADAM (1973).

\section{Rhogogaster chambersi BENSON, 1947}

Brandenburg: 7 larvae, $10-15 \mathrm{~mm}$ long, Landkreis Märkisch-Oderland, Müncheberg, Trebnitz, Schlag Dachsberge, $52.526^{\circ} \mathrm{N} 14.241^{\circ} \mathrm{E}, 28.06 .2015$ feeding on oilseed flax, Linum usitatissimum subsp. usitatissimum L. variety "Lirina".

The larvae were observed in hot, sunny conditions during the early afternoon. They are solitary. Some were found at rest, coiled on the leaf underside; smaller ones fed on leaf margins, whereas larger ones (Figs 7-8), probably in their final feeding instar, moved around a lot and mainly consumed leaves from the tip, but seldom ate more than about a quarter of the leaf. Because only seven larvae were found during a slightly more than two hour-long visual search of plants in a small area at the corner of the field (total area planted with Linum: $62.1 \mathrm{ha}$ ), R. chambersi cannot be stated to have been causing any significant damage to the part of the crop in which it was found. The larva and its behaviour have already been described in considerable detail by Chambers (1951). However, he recorded only Linum catharticum as a host: L. usitatissimum is apparently a new host plant record.

\section{*Tenthredo ignobilis KLUG, 1817}

Brandenburg: numerous larvae, Landkreis MärkischOderland, Jahnsfelde, $52.50961^{\circ} \mathrm{N} 14.24234^{\circ} \mathrm{E}$, field path, on S.telephium, 15.05.2010. 1 ㅇ, Müncheberg, Trebnitz, $52.53143^{\circ} \mathrm{N} 14.21674^{\circ} \mathrm{E}$, garden, flying around Sedum sp. cf. telephium, 21.05.2012; 1 larva (Fig. 9) on S. sp. cf. telephium, 23.06.2013. 1 larva, Landkreis Barnim, Friedrichswalde, Parlow, $53.02617^{\circ} \mathrm{N} 13.76203^{\circ} \mathrm{E}, 25.06$. 2015, garden, on S. sp. cf. telephium.

Since 2012 I have seen larvae every year, in greater or lesser numbers, on Sedum sp. cf. telephium in my garden at Trebnitz. Some plants were approximately $50 \%$ defoliated by the time the larvae stopped feeding.

\section{*Tenthredo semicolon MoL, 2013}

Brandenburg: 1 ㅇ, Landkreis Barnim, Eberswalde, $52.84^{\circ} \mathrm{N}$ $13.80^{\circ} \mathrm{E}, 06.06 .1965$, leg. J. Oehlke; 1 ㅇ, 14.08 .1985 , leg. A. Taeger. 1 ㅇ, Eberswalde-Finow, $52.84^{\circ} \mathrm{N} 13.74^{\circ} \mathrm{E}$, Teich, 27.05.1986, leg. A. Taeger. $1 \sigma^{\top}$, Sandkrug b. Eberswalde, $52.88^{\circ} \mathrm{N} 13.87^{\circ} \mathrm{E}, 28.07 .1971$, leg. J. Oehlke (in coll. United States National Museum, Washington DC).

First records from Germany.

Tenthredo punctulata KoNow, 1887 (primary homonym) was only recently removed from synonymy with Tenthredo colon KLUG, 1817, recognised to be a separate species, and re-named T. semicolon by A. Mol (in TAEgER 2013). Previously published information under the name T. colon on the larva, hosts and distribution may refer to either species. T. colon also occurs in Brandenburg: several specimens have been collected at Langer Berg, north of Eberswalde, in the Biosphere Reserve Schorfheide-Chorin, leg. DEI.

\section{Diprionidae}

\section{Microdiprion pallipes (Fallén, 1808)}

Brandenburg: 1 ㅇ, Landkreis Märkisch-Oderland, Müncheberg, NSG Gumnitz, $52.51^{\circ} \mathrm{N} 14.08^{\circ} \mathrm{E}, 30.04 .2006$.

Previously only known in Berlin-Brandenburg from old records (LisTon 2006b). 


\section{Pamphiliidae}

\section{${ }^{*}$ Cephalcia erythrogaster (HARTIG, 1837)}

Brandenburg: $10^{\star}$, Landkreis Havelland, Falkensee [„Berlin-Finkenkrug“],15.05.[1938], $52.55^{\circ} \mathrm{N} \quad 13.08^{\circ} \mathrm{E}$, leg. Zwick \& Roehl, det. L. Zombori / Liston (in coll. Hungarian Natural History Museum, Budapest).

\section{*Cephalcia abietis (Linnaeus, 1758)}

Berlin, $10^{\star}$, Marzahn, $52.545^{\circ} \mathrm{N} 13.548^{\circ} \mathrm{E}$, garden, 08.06. 2013, leg. A. Köhler. Brandenburg: $20^{\star}$, Landkreis Märkisch-Oderland, Müncheberg, Trebnitz, $52.53143^{\circ} \mathrm{N}$ $14.21674^{\circ} \mathrm{E}$, garden, $08 / 09.05 .2010 ; 1 \sigma^{\star}, 17.05 .2013$.

\section{Pamphilius inanitus (VILLERS, 1789)}

Brandenburg: 4 Larven in leaf-rolls on Rosa (Fig. 10), Landkreis Märkisch-Oderland, Müncheberg, Trebnitz, 52.53143 ${ }^{\circ} \mathrm{N} 14.21674^{\circ} \mathrm{E}$, garden, 05.07.2013.

The last record from Brandenburg was from before 1900 (BLANK et al. 2001).

\section{*Pamphilius pallipes (ZetTerstedt, 1838)}

Brandenburg: 1 ㅇ, Landkreis Barnim, Eberswalde, Finow, $52.84^{\circ} \mathrm{N} 13.74^{\circ} \mathrm{E}, 25.05 .1986$, leg. A. Taeger (in coll. South Central Forestry University, Changsha, China).

\section{Cephidae}

\section{Calameuta punctata (KLUG, 1803)}

Brandenburg: $1 \sigma^{\star}$, Landkreis Barnim, Niederfinow $1 \mathrm{~km} \mathrm{~S}, 52.828^{\circ} \mathrm{N} 13.937^{\circ} \mathrm{E}, 09.05 .2015 .2$ 우 , Landkreis Märkisch-Oderland, Müncheberg, Trebnitz, $52.535^{\circ} \mathrm{N}$ $14.204^{\circ} \mathrm{E}$, damp meadow, 16.05.2015. The females were swept from Alopecurus pratensis agg.; one of them while in the net still ovipositing in a portion of broken stem.

Calameuta punctata was mentioned as occurring in Germany by LisTON et al. (2012), without any further details, based on specimens collected in recent years by Mr Ewald Jansen in Saxony. Although the type locality of the species is Germany, probably Berlin-Brandenburg (KLUG 1803), the taxon was not mentioned in the checklists by BLANK et al. (1998) and BLANK et al. (2001). Alopecurus pratensis is the only recorded host (VIKBERG 1978: as Calameuta filum (GussakovskiJ, 1935)). The worldwide distribution extends westwards from Irkutsk in southern Siberia (VIITASAARI 1975), through Uzbekistan, Kasachstan (Zhelochovtsev \& Zinovjev 1996), the Caucasus (VirtasaAri 1975), Turkey (ÇAlmasur \& ÖzBEK 2010), and sporadically through much of central and eastern Europe (TAEger et al. 2006), reaching the Lake Ladoga Region of Russia (Humala \& Polevoi 2011) and southern Finland (VIITASAARI 1984) in the North. TAEger et al. (2006) listed C. punctata from Spain, citing the records by LLORENTE \& GAYUBO (1990) under the name C. pravei (DovnAR-ZAPOLSKIJ, 1926). C. pravei was treated as a synonym of C. punctata by ZoMBORI (1978), but this status requires confirmation. North of the Alps, the German localities seem to be the most westerly so far recorded. Males of $C$. punctata are much rarer than females in the northern parts of its range, and have for example not been found in Finland at all (VIITASAARI 1984).

\section{Xiphydriidae}

\section{Xiphydria megapolitana (BRauns, 1884)}

Brandenburg: 1 , Landkreis Märkisch-Oderland, Müncheberg, NSG Gumnitz, $52.509^{\circ} \mathrm{N} 14.080^{\circ} \mathrm{E}, 20.05$. 2011.

X. megapolitana was not listed from Berlin-Brandenburg by BLANK et al. (2001). However, a record of a female collected in 1900 by Oldenburg in "Berlin (Finkenkrug)" [now Brandenburg, Kreis Havelland, Falkensee] has already been published by JANSEN (1987).

\section{Discussion and conclusions}

It remains to be seen, whether Pristiphora angulata is actually established in Germany. Attempts to find the species on planted Spiraea in Berlin-Brandenburg during early 2015 did not yield any specimens. At present, I consider it premature to formally add P. angulata to the list of sawflies occurring in Germany. If found to be established, $P$. angulata would be one of only six neozoon sawfly species recorded in the country (four species so characterised by Liston et al. (2012), and Aproceros leucopoda subsequently added by BLANK et al. (2014)). In analogy with Coleophora spiraeella (REBEL, 1916) (Lepidoptera), which also has Spiraea chamaedryfolia as a main host, it would be worthwhile searching for P. angulata in and near the Oberlausitz (Saxony), where C. spiraeella has been recorded (LEUTSCH 2001).

Blank et al. (2001) and Liston (2006b) recorded a total of 467 species of Symphyta in Berlin-Brandenburg. BLANK et al. (2014) added Aproceros leucopoda TAKeUCHI, 1939. With the addition here of 24 species newly recorded (excluding Pristiphora angulata) and three confirmed, and the deletion of Dineura testaceipes, 494 species are now recorded in these provinces. This represents approximately $65 \%$ of the total of 758 species currently recorded in Germany.

Of the species newly recorded in Brandenburg, or here confirmed, Calameuta punctata is noteworthy because it is one of the small number of sawfly species which have 
a mainly eastern distribution in Europe, and in Germany are so far only recorded from the extreme East of the country. Other such species which occur in Brandenburg are Caenocephus lunulatus (StroвL, 1895), Corynis amoena (KLUG, 1834) and Nematus lucens (ENSLIN, 1918). Dineura parcivalvis may have a similar distribution, based on what is so far known, or could have been overlooked in territories further west because it has been confused with $D$. testaceipes.

\section{Acknowledgements}

For the opportunity to examine specimens in public collections, I thank the following curators: Dr Sandor Czösz (formerly Hungarian Natural History Museum, Budapest), Dr Frank Koch (Museum für Naturkunde, Berlin), Richard Lyzkowski (National Museums of Scotland, Edinburgh), Dr Stephan Schmidt (Zoologische Staatssammlung, München) and Dr Hege Vårdal (Swedish Museum of Natural History, Stockholm). Through Genome Canada and the Ontario Genomics Institute, funding was provided to the International Barcode of Life Project by the government of Canada, which enabled staff at the Canadian Centre for DNA Barcoding (University of Guelph) to carry out sequence analysis of mitochondrial DNA (CO1) on some specimens. I also thank the Ontario Ministry of Economic Development and Innovation for informatics support provided through the Barcode of Life Data Systems (BOLD), and particularly Dr Julie Stahlhut (Guelph) for her assistance in the processing of samples. Dr Andreas Taeger and Dr Marko Prous (Müncheberg) kindly read a draft of the manuscript and suggested some improvements.

\section{References}

ADAM, H. 1973: Beitrag zur Populationsdynamik einheimischer Blattwespen am Beispiel der Gattung Pristiphora Latreille, 1810. - Beiträge zur Entomologie, Berlin 23 (1-4): 219-239.

BENEš, K. 2015: Czech species of the gall-making sawflies of the genera Phyllocolpa, Tubpontania and Pontania (Hymenoptera, Nematinae). - Acta Musei Moraviae, Scientiae biologicae, Brno 100 (1): 137-156.

Benson, R. B. 1958: Hymenoptera, Symphyta. - Handbooks for the Identification of British Insects, London 6 (2c): 139-258.

Blank, S. M.; Boevé, J.-L.; Heitland, W.; Jänicke, M.; Jansen, E.; Koch, F.; Kopelke, J.-P.; Kraus, M.; Liston, A. D. \& Ritzau, C. 1998: Checkliste der Pflanzenwespen Deutschlands (Hymenoptera: Symphyta): pp. 13-34. - In: Taeger, A. \& Blank, S. M. (eds) Pflanzenwespen Deutschlands (Hymenoptera, Symphyta). Kommentierte Bestandsaufnahme. Goecke \& Evers, Keltern.
Blank, S. M.; Deters, S.; Drees, M.; Jänicke, M.; Jansen, E.; Kraus, M.; Liston, A. D.; Ritzau, C. \& Taeger, A. 2001: Symphyta. - In: Dathe, H. H.; Taeger, A. \& Blank, S. M. (Eds): Verzeichnis der Hautflügler Deutschlands (Fauna Germanica 4). Entomologische Nachrichten und Berichte, Dresden Beiheft 7: 8-27.

Blank, S. M.; Köhler, T.; Pfannenstill, T.; Neuenfeldt, N.; Zimmer, B.; Jansen, E.; TAeger, A. \& Liston, A. D. 2014: Zig-zagging across Central Europe: recent range extension, dispersal speed and larval hosts of Aproceros leucopoda (Hymenoptera, Argidae) in Germany. - Journal of Hymenoptera Research, Sofia 41: 57-74.

Çalmasur, Ö. \& ÖzbeK, H. 2010: Distribution data on the Cephidae (Hymenoptera: Symphyta) fauna of Turkey. - Zoology in the Middle East, Heidelberg 50: 144-146.

Chambers, V. H. 1951: The larva and foodplant of Rhogogaster chambersi Benson (Hym., Tenthredinidae). - The Entomologist's Monthly Magazine, Fourth Series, London 87 (12): 202-205.

DeWaard, J.; Ivanova, N.; Hajibabaei, M. \& Hebert, P. 2008: Assembling DNA barcodes. Analytical protocols. Pp. 275-293. - In: Martin, C. (Ed.) Methods in Molecular Biology: Environmental Genetics. Humana Press Inc., Totowa.

HeidemaA, M.; Nuorteva, M.; Hantula, J. \& SAARMA, U. 2004: Dolerus asper ZadDACH, 1859 and Dolerus brevicornis ZADDACH, 1859 (Hymenoptera: Tenthredinidae), with notes on their phylogeny. European Journal of Entomology, Ceské Budejovice 101 (4): 637-650.

Humala, A. E. \& Polevoi, A. V. 2011: [Records of new and remarkable insect species (Insecta) in northern Ladoga area.]. - Trudy Karel'skogo nauchnogo centra RAN 2: 142-144.

Ivanova, N. V.; DewaARd, J. R. \& Hebert, P. D. N. 2006: An inexpensive, automation-friendly protocol for recovering high-quality DNA. - Molecular Ecology Notes 6 (4): 998-1002.

Jansen, E. 1987: Die europäischen Arten der Gattung Konowia Brauns (Hymenoptera: Xiphydriidae). - Stuttgarter Beiträge zur Naturkunde. Serie A (Biologie), Stuttgart 4: 1-12.

KLUG, F. 1803: Monographia Siricum Germaniae atque generum illis adnumeratorum. - Berolini, F. Schüppel: i-xii, 1-64, 7 unpag.

Kontuniemi, T. 1960: [Dineura parcivalvis (Knw) lajin (Hym., Tenthredinidae) bionomiasta]. (Zur Bionomie von Dineura parcivalvis Knw.) - Annales Entomologici Fennici, Helsinki 26 (4): 296, 303.

Kopelke, J.-P. 2007: The European species of the genus Phyllocolpa, part I: the leucosticta-group (Insecta, Hymenoptera, Tenthredinidae, Nematinae). Senckenbergiana Biologica, Frankfurt/M. 87 (1): 75-109. 
Leutsch, H. 2001: Neufunde, Bemerkungen und Korrekturen zur Fauna der Coleophoridae in der Oberlausitz (Lep.). - Entomologische Nachrichten und Berichte, Dresden 45 (2): 115-118.

LINDQVisT, E. 1955: Beitrag zur Kenntnis einiger nordischen Blattwespen (Hym., Tenthredinoidea). Notulae Entomologicae, Helsinki 35: 137-144.

LINDQvist, E. 1972: Zur Nomenklatur und Taxonomie einiger Blattwespen (Hymenoptera, Symphyta). Notulae Entomologicae, Helsinki 52: 65-77.

Liston, A. D. 2006a: Notes on Empria hungarica (KonOw, 1895), an addition to the German sawfly fauna (Hymenoptera, Tenthredinidae). - Nachrichtenblatt der Bayerischen Entomologen, München 55 (1/2): 7-10.

Liston, A. D. 2006b: Beitrag zur Pflanzenwespenfauna von Brandenburg und Berlin (Hymenoptera, Symphyta). - Nachrichtenblatt der Bayerischen Entomologen, München 55 (3/4): 65-76.

Liston, A. D. 2011: Pflanzenwespen. - In: Nationalparkverwaltung Bayerischer Wald (Hrsg.): Biologische Vielfalt im Nationalpark Bayerischer Wald. - Sonderband der Wissenschaftlichen Schriftenreihe des Nationalparks Bayerischer Wald, Grafenau: 184-187.

Liston, A. D.; Jansen, E.; Blank, S. M.; Kraus, M. \& TAeger, A. 2012: Rote Liste und Gesamtartenliste der Pflanzenwespen (Hymenoptera: Symphyta) Deutschlands. Stand März 2011: pp.489-556. In: Binot-Hafke, M.; Balzer, S.; Becker, N.; Gruttke, H.; Haupt, H.; Hofbauer, N.; Ludwig, G. \& STrauch, M. (Eds): Rote Liste gefährdeter Tiere, Pflanzen und Pilze Deutschlands. Wirbellose Tiere Teil 1. - Naturschutz und Biologische Vielfalt, BonnBad Godesberg 70 (3): 1-716.

Llorente, G. \& Gayubo, S. F. 1990: Estudio sobre la sinfitofauna del oeste español. I (Hymenoptera, Symphyta). - EOS. Revista Espanola de Entomología, Madrid 65 (2): 23-29.

LöHR, P.-W. 2015: Die Pflanzenwespen-Fauna (Hymenoptera: Symphyta) eines xerothermen Hanges bei Lorch im Oberen Mittelrheintal. - Hessische Faunistische Briefe, Darmstadt 34 (1/2): 29-35.

Lønnve, O. J. 2009: Notes on Norwegian sawflies (Hymenoptera, Symphyta) II. 13 species new to the Norwegian Fauna. - Norwegian Journal of Entomology, Oslo 56: 50-56.

Muche, W. H. 1968: Beitrag zur Blattwespenfauna der Umgebung von Eberswalde (Hymenoptera, Tenthredinoidea). - Faunistische Abhandlungen Staatliches Museum für Tierkunde Dresden, Leipzig 2 (15): 107-108.

Prous, M.; $\quad$ Blank, S. M.; $\quad$ Goulet, H.; Heibo, E.; Liston, A.; Malm, T.; Nyman, T.; Schmidt, S.; SMith, D. R.; VARdAl, H.; VittasaARI, M.; Vikberg, V. \& TAeger, A. 2014: The genera of Nematinae (Hymenoptera, Tenthredinidae). - Journal of Hymenoptera Research, Sofia 40: 1-69.
Prous, M.; HeidemaA, M. \& Soon, V. 2011: Empria longicornis species group: taxonomic revision with notes on phylogeny and ecology (Hymenoptera, Tenthredinidae). - Zootaxa, Auckland 2756: 1-39.

Schedl, W. \& Altenhofer, E. 2013: Zur Morphologie, Biologie und Verbreitung von Spinarge metallica (KLUG 1834) in Österreich (Hymenoptera: Argidae). - Linzer biologische Beiträge, Linz 45 (1): 663-669.

Schirmer, C. 1901: Verzeichnis der in der Umgebung Berlins beobachteten Tenthrediniden (Blatt- und Holzwespen). - Allgemeine Zeitschrift für Entomologie, Neudamm 6: 279-282, 293-296.

TAeger, A. 2013: The type specimens of Tenthredo LinnaEus, 1758 (Hymenoptera: Tenthredinidae) deposited in the Hungarian Natural History Museum. - Zootaxa, Auckland 3626 (2): 201-244.

Taeger, A.; Altenhofer, E.; Blank, S. M.; Jansen, E.; Kraus, M.; Pschorn-Walcher, H. \& Ritzau, C. 1998: Kommentare zur Biologie, Verbreitung und Gefährdung der Pflanzenwespen Deutschlands (Hymenoptera, Symphyta). pp.49-135. - In: TAeger, A. \& Blank, S. M. (Eds): Pflanzenwespen Deutschlands (Hymenoptera, Symphyta). Kommentierte Bestandsaufnahme. - Goecke \& Evers, Keltern.

Taeger, A.; Blank, S. M. \& Liston, A. D. 2006: European Sawflies (Hymenoptera: Symphyta) - A Species Checklist for the Countries. pp.399-504. - In: Blank, S. M.; Schmidt, S. \& TAeger, A. (Eds) 2006: Recent Sawfly Research: Synthesis and Prospects. Goecke \& Evers, Keltern.

VittasaARI, M. 1975: On the genera Janus Lepeletier and Calameuta Konow (Hym., Cephidae) in Eastern Fennoscandia. - Annales Entomologici Fennici, Helsinki 41 (4): 113-120.

VittASAARI, M. 1984: Sahapistiäiset 3. Siricoidea, Orussoidea and Cephoidea. - Reports, University of Helsinki, Department of Agricultural and Forest Zoology, Helsinki 6: 1-66.

VIKBERG, V. 1978: [Calameuta filum (GussakovskiJ) (Hymenoptera, Cephidae) found in South Häme] (In Finnish). - Notulae Entomologicae, Helsinki 58 (4): 176-177.

Zhelochovtsev, A. N. \& Zinovjev, A. G. 1996: Spisok pilil'shhikov i rogohvostov (Hymenoptera, Symphyta) fauny Rossii i sopredel'nyh territorij. II. [A list of the sawflies and horntails (Hymenoptera, Symphyta) of the fauna of Russia and adjacent territories. II.] (In Russian, abstract in English). Entomologicheskoe obozrenie, St. Peterburg 75 (2): 357-379.

Zombori, L. 1978: New Sawfly Species in the Hungarian Fauna (Hymenoptera, Symphyta), IV. - Annales historico-naturales Musei Nationalis Hungarici, Budapest 70: 259-264. 

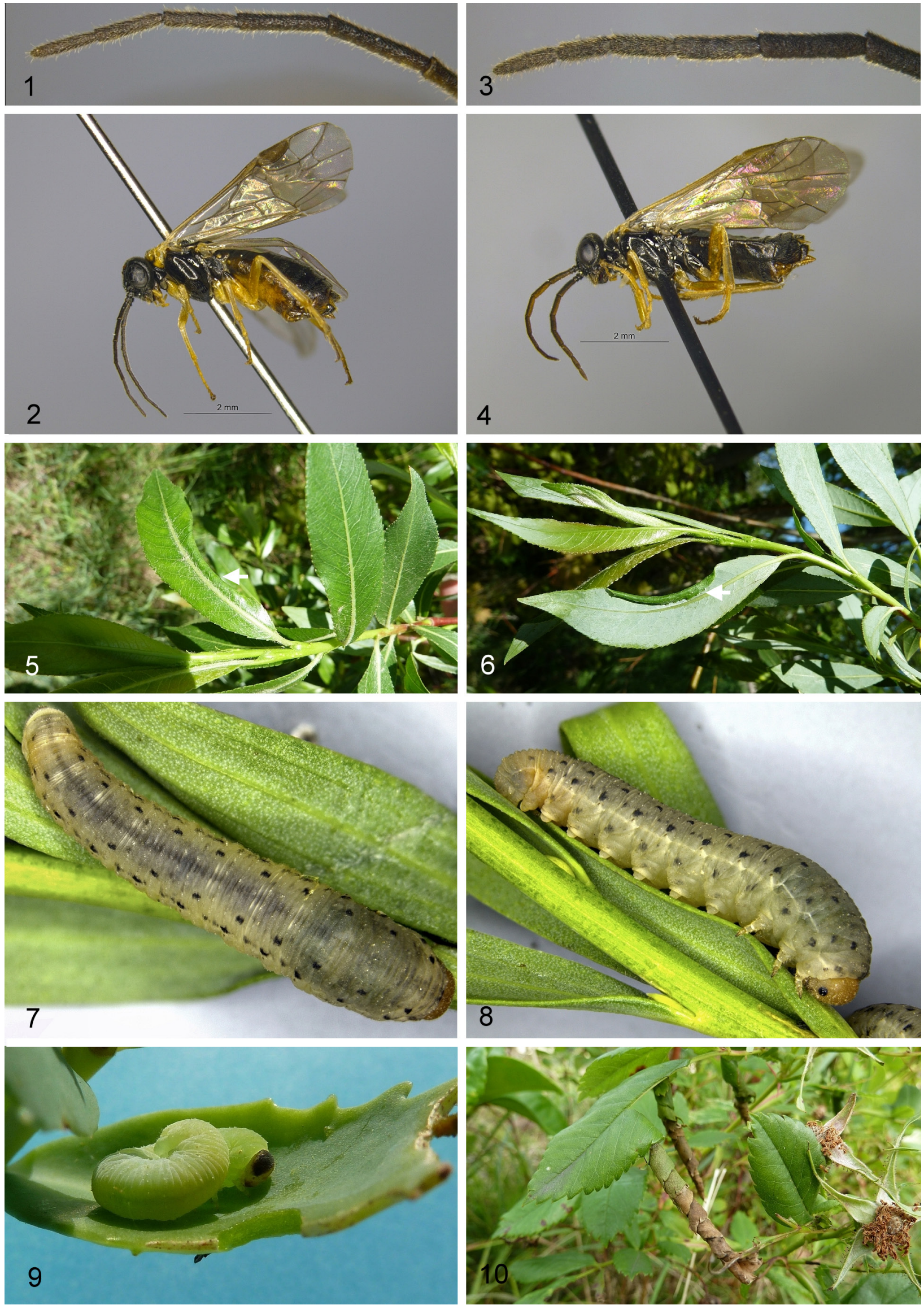

Figs 1-2: Dineura parcivalvis, ‥ 1: apical flagellomeres. 2: coloration. - Figs 3-4: Dineura testaceipes, ‥ 3: apical flagellomeres. 4: coloration. - Figs 5-6: Euura plicadaphnoides, galls (arrowed) on leaves of Salix daphnoides. - Figs 7-8: Rhogogaster chambersi, larva on Linum usitatissimum. - Fig. 9: Tenthredo ignobilis, larva on Sedum telephium. - Fig. 10: Pamphilius inanitus, leaf rolls on Rosa sp. 